\title{
ПРАГНЕННЯ ДО САМОАКТУАЛІЗАЦІЇ ЯК ІНТЕГРАТИВНИЙ ПОКАЗНИК РОЗВИТКУ СУБ'ЄКТНОЇ ПОЗИЦІЇ СУЧАСНОГО СТУДЕНТА
}

\section{Вовк Валентина Олегівна}

\author{
Аспірантка кафедри педагогічної та вікової пси- \\ хології ДВНЗ «Прикарпатський національний \\ університет імені Василя Стефаника», м. Терно- \\ піль (Україна)
}

\begin{abstract}
Анотація. У статті актуалізована проблема суб'єктної позиції у студентському віці. Зокрема, здійснене дослідження проявів прагнення до самоактуалізаиії як одного із визначальних показників розвитку суб'єктної позииії особистості майбутнього фахівия. На теоретичному рівні розглянуто розуміння самоактуалізаиії зарубіжними та вітчизняними дослідниками. На емпіричному рівні здійснена діагностика та трунтовний аналіз особливостей самоактуалізаиії студентів різних спеціальностей.
\end{abstract}

Ключові слова: позииія, суб'єктна позииія майбутнього фахівия, самоактуалізаиія, сенситивність, автономність, саморозуміння, самоповага, синергія.

Постановка проблеми. Освіта - це та сфера становлення особистості, де закладаються механізми саморозвитку, котрі ведуть людину як суб'єкта власної діяльності до духовного вдосконалення. Напевне, не можна стверджувати, що лише самоактуалізація повинна стати метою чи сенсом вищої освіти. Проте, якщо мати на увазі, що потреби самовизначення, реалізації фізичних та психічних сил найбільш актуальні у юнацькому віці, то дуже важливо створити освітні умови для реалізації прагнення до самоактуалізації. Смисло- вий простір освіти повинен здійснювати зв'язок суб' єкта освітнього процесу зі світом культури, аналізуючи потенціал самоорганізації і саморозвитку, створюючи умови для осмисленого, суб'єктивно включеного учіння [6].

\section{Аналіз останніх досліджень i} публікацій. В теперішній час суб'єктна позиція майбутнього фахівця як предмет дослідження вчених різних галузей гуманітарного знання, набуває все більший інтерес. Особливу значимість мають праці, в яких розкривається сутність феномену суб'єктності 
українськими та зарубіжними вченими (3. М. Адамська, О. М. Волкова, 3. С. Карпенко, О. О. Конопкін, B. А. Петровский, В. I. Слободчиков, В. А. Татенко, Г. К. Радчук, С. Л. Рубінштейн та ін.); теорії розвитку суб'єктності в системі вищої освіти (I. Д. Бех, Ж. П. Вірна, B. В. Давидов, О. О. Деркач, С. Д. Максименко, М. В. Савчин, Ю. М. Швалб, Т. С. Яценко та ін.); дослідження компонентів суб'єктного досвіду (О. К. Осницький); становлення суб'єктної позиції особистості в процесі фахової освіти та професійної діяльності у працях психологів та педагогів (Г. І. Аксьонова, Ю. Л. Блінова, Е. Н. Залевска, Е. К. Дворянкіна, Ю. Л. Кузнецова, А. С. Лебедєв, Т. О. Ольхова та Г. К. Радчук та ін.).

Разом 3 тим, аналіз теорії і практики вказують на недостатність наукового обгрунтування цілісної концепції розвитку суб'єктної позиції майбутнього фахівця, наявності низки протиріч між вимогами до рівня ï розвитку та відчутною нестачею знань про особливості становлення означеного феномену в процесі професійної підготовки, відсутності стратегії реалізації цього процесу в практиці вищої школи.

Мета статті полягає в теоретичному аналізі змісту поняття «самоактуалізації» та емпіричному вивченні даної проблеми у студентів різних спеціальностей.

\section{Виклад основного матеріалу дослі-}

дження. Позиція особистості, як стверджується психологами (К. О. АбульхановоюСлавською, Б. Г. Ананьєвим, Л. І. Божович, О. М. Лєонтьєвим, В. Ф. Сафіним, В. В. Століним) та педагогами (Н. М. Боритко, О. О. Мацкайловою, В. В. Сєриковим) - це складна система ставлень, установок та мотивів особистості, котрими вона керується у своїй діяльності, цілей та цінностей, на які спрямована ця діяльність.

На нашу думку, суб'єктна позиція майбутнього фахівця - це система особистіснозначущих, ціннісно-смислових ставлень до процесу навчання, до обраної професії, до себе як до фахівця і свого майбутнього професійного шляху, спрямованих на саморозвиток та самоактуалізацію. Вона характеризується властивостями суб'єкта та реалізується у таких функціях як самопізнання, саморозуміння, самооцінка, самореалізація, самоствердження, саморозвиток, самовдосконалення.

Погоджуючись 3 H. M. Боритко, Ф. I. Блієвою, О. А. Мацкайловою, Г. К. Радчук, вважаємо, що інтегративним показником суб'єктної позиції студента є прагнення до самоактуалізації, котра є провідним мотивом, що спонукає до максимальних досягнень у майбутній професії. Різні автори називають іiі по-різному: самоактуалізація, сенс життя, інтеграція, психічне здоров'я, індивідуація, автономія, продуктивність [2], але всі вони одностайні в тому, що все це синоніми реалізації потенцій індивіда в повному сенсі 
цього слова, становлення тим, ким він може стати.

Введення поняття «самоактуалізація»у психологію пов'язане із ім'ям К. Гольдштейна, який розглядав іï як фундаментальний процес в кожному організмі, основу розвитку i вдосконалення організму, творчу тенденцію людської природи. Учений вважав, що для здорового організму первинною метою є формування певного рівня напруги, який зробить можливою подальшу впорядкованість діяльності, непозначаючи кінець проблемам і труднощам, a, навпаки, діяльність, що супроводжується певною часткою невпевненості i страждання.

Представники психоаналітичної школи спробували побачити в домінантних інстинктах людини потребу в самореалізації. Так, самореалізація, за 3. Фрейдом, локалізується в несвідомому шарі людської психіки і виявляється в «прагненні до задоволення», властивому людині з народження. Цій інстинктивній потребі в самореалізації протистоять нав’язані суспільством імперативні вимоги культури (норми, традиції, правила i т.д.), основна функція яких полягає в цензурі за несвідомим, в придушенні інстинкту подібних потреб.

У роботах К. Юнга для позначення процесу особистісного зростання використовується термін «індивідуація», що означає «шлях до себе» або «самореалізацію», метою якої $€$ набуття внутрішнього стрижня, усвідомлення людиною певного центру в ii психічному бутті. У завершеній своїй формі індивідуація - це свідома реалізація особистістю своєї унікальної психічної реальності, повний розвиток і виявлення всіх елементів особистості [4].

Основи теорії самоактуалізації на грунті екзистенційної філософії (Ф. Брентано, М. Бубер, Е. Гуссерль, А. Камю, С. К'єркегор, М. Гайдеггер, Ж-П. Сартр, К. Ясперс) заклали представники гуманістичної психології А. Адлер, Ш. Бюллер, Дж. Олпорт, К. Роджерс, Х. Когут, Р. Мей, К. Хорні, А. Маслоу, В. Франкл, Е. Шостром.

Одне із основних понять концепції А. Адлера [1] - це «творча сила», тобто суб'єктна активність, що відповідає за стратегію і життєву тактику людини в процесі самоактуалізаiï. Людина відповідальна за свої цінності і установки, оскільки вона використовує спадковість і соціальне оточення для формування власної особистості.

У поглядах К. Роджерса тенденція до самоактуалізації - це не просто один із мотивів: «Це прагнення, яке простежується у всьому органічному і людському житті, прагнення поширюватися, ставати зрілим, прагнення виражати і задіювати усі здібності організму, в тій мірі, в якій ця дія посилює організм або самість» $[5$, с. 381$]$.

Однією 3 найбільш широко відомих теорій в рамках екзистенційно-гуманістичного напрямку в психології є концепція А. Маслоу. Поняття самоактуалізації у А. Маслоу синте- 
тичне, що включає всебічний і безперервний розвиток творчого і духовного потенціалу людини, максимальну реалізацію усіх можливостей, адекватне сприйняття оточення, світу і свого місця у ньому, багатство емоційної сфери і духовного життя, високий рівень психічного здоров'я і моральності. В одній зі своїх праць учений визначає самоактуалізацію як прагнення до самоздійснення, точніше, тенденцію актуалізувати те, що міститься в особистості в якості потенцій, як головний мотиваційний чинник сходження людини до індивідуальності на основі чуттєвого переживания потреби у вдосконаленні [2]. Автор описує наступні характеристики самоактуалізованої особистості:

- спротив прилучення до культурних норм;

- власна система цінностей;

- $\quad$ пікові переживання;

- свіжість сприймання: здатність переживати прості радощі життя, приймати як чудо те, що для інших стало звичним та буденним;

- спонтанність: поведінка відрізняється простотою та природністю;

- прийняття: відсутність домінуючого почуття провини або сорому;

- $\quad$ людська спорідненість: відчуття істинного бажання принести користь всьому людству;

- $\quad$ автономія: відносна незалежність від фізичного та соціального оточення, незалежність від ставлень оточуючих; центування на проблемі; креативність [6].

Поняття самоактуалізації і особистості, що самоактуалізується А. Маслоу, подібне до понять «особистість 3 повним функціонуванням» у феноменологічному підході К. Роджерса, «аутентичної особистості» в гештальттерапії Ф. Перлса. О. С. Штепою був проведений контент-аналіз переліку особистісних характеристик особистості, яка продуктивно розвивається за працями К. Юнга, Г. Олпорта, В. Штерна, Е. Фромма, В. Франкла, А. Менегетті, Р. Ассаджолі, К. Роджерса, А. Маслоу, Е. Шострома, Ф. Перлза, А. О. Реана, Г. С. Абрамової, Л. І. Божович та інших, в результаті чого виведені риси та названі «пропріумом зрілої особистості». Синергічність, автономність, контактність, самоприйняття, креативність, толерантність, відповідальність, глибинність переживань, здатність до децентрації та наявність власної життєвої філософії складають «пропріумом зрілої особистості». Перші п’ять рис на думку О. С. Штепи є яскравою ознакою особистості, що самоактуалізується. У той же час сама по собі самоактуалізація є одночасно ознакою і процесом кристалізації пропріуму зрілої особистості. Змістовно ці характеристики є такими. Синергічність характеризується здатністю до цілісного сприйняття світу та людей, до розуміння взаємопов'язаності суперечностей. 
Автономність виявляється у вмінні довіряти власним судженням та діяти відповідно до них, наявності власної, незалежної від оточення системи цінностей. Контактність характеризує здатність до швидкого встановлення глибоких контактів 3 людьми. Самоприйняття - безоцінкове позитивне ставлення до себе, незважаючи на існуючі недоліки. Креативність - здатність до створення чогось нового, чого раніше не було, творча спрямованість [7].

Узагальнюючи сказане, автор робить висновок, що особистісне зростання характеризується процесом внутрішньо-особистісної трансформації, джерелом якої є потреба особистості у самоактуалізації та відчутті ідентичності. Результатом трансформації $\epsilon$ відповідальна побудова людиною власної концепції життя згідно з загальними моральними принципами та особистісною місією.

У вітчизняній психології найвідоміші дослідження самоактуалізації особистості пов'язані 3 іменами Л. С. Виготського, С. Л. Рубінштейна, О. М. Леонтьєва, Г. С. Костюка, К. К. Платонова, Г. О. Балла.

Зокрема С. Л. Рубінштейн, визначає поняття самоактуалізації через категорію «спрямованості». Він розглядає цей феномен як інтегральну характеристику особистості, що поєднує і динамічне, і змістове, і ставленнєве (емоційне), де на новому рівні розкриваються вольові якості особистості в тому сенсі, наскільки й у якому напрямі зуміла особистість додати єдності своїм потягам, бажан- ням і застосувати свою волю для їх реалізації в особистісно-ціннісних і суспільно значущих формах.

Важливим $є$ погляд Л. І. Божович, яка визначає зростаючу особистість як ініціатора власної активності, підгрунтя якої знаходиться в мотиваційно-потребовій сфері. Ця активність становить основу розвитку особистості як суб'єкта. За іiі словами дитина поступово перетворюється 3 істоти, підпорядкованої зовнішнім впливам, на суб'єкта, здатного діяти самостійно на основі свідомо поставлених цілей і прийнятих намірів. Хоча в концепції Л.І. Божович і не вживається термін «самоактуалізація», процес іiі досліджується і пов'язується 3 терміном «суб'єкт», який виступає у вигляді важливої якості особистості, що полягає в здатності оволодіти світом, створювати себе, створювати щось нове, суто своє, в соціумі [3].

Узагальнюючи підходи до визначення процесу самоактуалізації особистості, ми можемо зробити висновок, що поняття «самоактуалізація» об'єднує різні концепції розвитку людини і суспільства, що грунтуються на ідеї саморозвитку і самоорганізації та припускають максимально ефективне використання людиною усієї сукупності своїх здібностей, умінь, навичок і психофізіологічних ресурсів. Прагнення до реалізації своїх можливостей закладено в кожній людині i, на думку представників різних психологічних шкіл, є iii найважливішою, центральною якістю, необ- 
хідним атрибутом життєдіяльності здорової, зрілої особистості. Таким чином, самоактуалізація визначається нами як психічне явище, котре може трактуватися як процес, стан, інтенція, потреба, результат і властивість особистості, що знаходиться у когруентних стосунках із самопізнанням і самовдосконаленням та забезпечує соціальну «ефективність» особистості.

Аналіз психологого-педагогічної літератури дає можливість визначити самоактуалізацію особистості в процесі здобуття фахової освіти як процес найбільш повного втілення студентом власного інтелектуального, духовного, морального, творчого, комунікативного, енергетичного та інших потенціалів особистості в учбово-професійній діяльності, спілкуванні, праці і дозвіллі. Самоактуалізація особистості студента розглядається навіть не стільки як мета, скільки як шлях суб'єктного становлення, оскільки передбачає саморозвиток самозміну, самопізнання. Суб'єкт (особистість, що самоактуалізуєтся) ставить мету, перетворює іiї в життєву задачу, для чого сам переструктуровує власний внутрішній світ, і стає причиною своїх ставлень зі світом, із суспільством; $є$ творцем власного життя, створює умови свого розвитку; долає деформацію власної особистості. Характеристиками особистості, яка самоактуалізується у професійній діяльності виділяються [2]: емоційне переживання повноти життя; безперервне прагнення до особистісно-професійного самовдо- сконалення; отримання задоволення від самого процесу професійної діяльності; здатність до усвідомленого вибору в складних ситуаціях і до прийняття відповідальності за його наслідки.

3 метою вивчення особливостей та рівня прояву самоактуалізації сучасних студентів у процесі фахової підготовки у вищому навчальному закладі ми використали самоактуалізаційний тест (САТ) Е. Шострома в адаптації Ю. О. Альошиної, Л. Я. Гозмана. Дана методика включає 14 шкал, з яких 2 основні і 12 - додаткові: 1) компетентність у часі; 2) підтримка; 3) ціннісні орієнтації; 4) гнучкість поведінки; 5) сенситивність (чутливість) до себе; 6) спонтанність; 7) самоповага; 8) самоприйняття; 9) уявлення про природу людини; 10) синергія; 11) прийняття власної агресії; 12) контактність; 13) пізнавальні потреби; 14) креативність.

Таким чином, кожен випробуваний має в підсумку 14 показників самоактуалізації особистості. Дані показники заносяться на спеціальний бланк, на якому вони співвідносяться з допомогою масштабної сітки. Вважається, що випробуваний досягнув оптимального рівня самоактуалізації особистості, якщо його дані перебувають у діапазоні 55-56\%.

Вивчення особливостей самоактуалізації здійснювалося на сукупній вибірці студентів першого, другого, третього та п'ятого курсів навчання технічних, педагогічних, психо- 


\section{Розподіл середніх показників за шкалами САТ}

у студентів $(\mathrm{n}=\mathbf{2 4 3})$

\begin{tabular}{|l|c|c|c|c|c|}
\hline \multirow{2}{*}{ Шкали } & \multicolumn{5}{c|}{ Одержані результати (\%) } \\
\cline { 2 - 6 } & I курс & II курс & III курс & V курс & Уся \\
\hline Компетентність у часі & & & & 44,96 \\
\hline Підтримка & 46,14 & 45,58 & 42,23 & 44,69 & 49,75 \\
\hline Ціннісна оріснтація & 47,35 & 48,58 & 50,13 & 53,80 & 50,65 \\
\hline Гнучкість поведінки & 49,90 & 48,56 & 51,74 & 52,64 & 46,67 \\
\hline Сенситивність до себе & 44,62 & 47,39 & 47,96 & 48,08 & 49,82 \\
\hline Спонтанність & 49,34 & 48,90 & 52,13 & 49,64 & 59,06 \\
\hline Самоповага & 45,79 & 49,49 & 52,48 & 50,95 & 52,34 \\
\hline Самоприйняття & 51,43 & 54,54 & 51,81 & 52,19 & 46,29 \\
\hline Уявлення про природу людини & 45,22 & 46,33 & 44,90 & 48,72 & 52,95 \\
\hline Синергія & 54,82 & 48,47 & 51,30 & 55,16 & 51,74 \\
\hline Прийняття агресї & 50,66 & 49,37 & 49,48 & 56,75 & 48,52 \\
\hline Контактність & 48,27 & 47,66 & 48,88 & 49,32 & 49,52 \\
\hline Пізнавальні потреби & 50,68 & 49,11 & 45,60 & 50,95 & 43 \\
\hline Креативність & 42,01 & 42,50 & 38,86 & 47,66 & 47,56 \\
\hline
\end{tabular}

логічних та медичних спеціальностей. Загальний обсяг вибірки - 243 особи.

Отримані результати дослідження вказують (таблиця 1), що у студентів спостерігається низький рівень тенденції до самоактуалізації, так як показники майже за усіми шкалами недосягають оптимального значення 55$56 \%$. Найвищі показники у студентів виявлені за такими шкалами: «Уявлення про природу людини» (52,95\%), «Самоповага» $(52,34 \%$, «Синергія» $(51,74 \%)$ та «Ціннісна орієнтація» $(50,65 \%)$. Найнижчі показники діагностовано за шкалами «Компетентність у чаci» $(44,96 \%)$ та «Пізнавальні потреби» (43\%). Проаналізуємо їх детальніше.
За шкалою «Компетентність у часі» виявили, що досліджувані занурення в минулі переживання, схильні відкладати своє теперішнє життя на потім. Про що свідчать отримані показники, зокрема у студентів першого курсу - це 46,14\%, у другокурсників - 45,58\%, у третьокурсників - 42,23\% і у студентів п'ятого курсу - 44,69\%. Окрім того з таблиці 1, бачимо чітку тенденцію до зниження показників 3 першого до третього курсу, проте у випускників фіксується невелике зростання відсотків, що дає підставу стверджувати про можливість появи у студентів розуміння екзистенціальної цінності життя «тут і тепер», здатності насолоджуватися актуальним моментом, минулим 
і теперішнім.

За допомогою шкали «Підтримка», діагностували рівень незалежності суб'єкта від зовнішніх впливів. Одержані значення вказують на зростання показників від 47,35\% на першому курсі до 53,80\% на п'ятому курсі. Можна сказати, що у студетів поступово розвивається відносна автономність у своїх вчинках та стремління керуватися у житті власними цілями, переконаннями, установками.

Показник нижче оптимального рівня виявлено у третьокурсників (51,74\%) та у випускників (52,64\%) за шкалою «Ціннісна орієнтація», а це свідчить що молоді люди не зовсім поділяють цінності самоактуалізованих особистостей, до числа яких А. Маслоу відносив істину, життєрадісність, добро, красу, цілісність, порядок, досконалість, справедливість, самодостатність, легкість без зусиль. Найнижчі значення за досліджуваним параметром у другокурсників $\quad-48,56 \%$. Їм властива схильність до маніпуляції людьми у своїх інтересах, незадоволеність минулою дійсністю і теперішньою реальністю.

За наступною шкалою «Гнучкість поведінки» діагностовано найнижчий показник у першокурсників (44,62\%), найвищий у випускників (48,08\%), у студентів другого та третього курсів - 47,39\% та 47.96 відповідно. Можна стверджувати, що студенти несхильні до гнучкої взаємодії з оточуючим середовищем, не вміють швидко та адектватно реагувати в будь-якій ситуації. Проте аналізуючи таблицю
1, прослідковуємо тенденцію до можливого розвитку означених вмінь, адже середні значення від першого до п'ятого курсів дещо зростають.

За шкалою «Сенситивність до себе» найвищий розвиток досліджуваного параметру виявлено у третьокурсників (52,13\%), найнижчий у другокурсників (48,90\%), у студентів першого - 49,34\% та п'ятого курсів 49,64\%. Такі результати свідчать про недостатню схильність усвідомлювати та розуміти власні потреби і почуття, невміння відчувати та рефлексувати їх.

Наступною характеристикою самоактуалізованої особистості є спонтанність - це якість, яка означає вільне виявлення своєї особистості, відсутність комплексів неповноцінності, страху здатися смішним, нетактовним тощо. Інакше кажучи, простота, довіра до життя. Аналізуючи таблицю 1 бачимо, що найвищий показник за шкалою у досліджуваних третього курсу (52,48\%), трохи нижчий - у випускників (50,95\%) та студентів другого (49,49\%). Такі результати є свідченням того, що майбутні фахівці не завжди поводять себе природньо та розкуто, бояться демонструвати оточуючим свої емоції. Опитувані першого курсу отримали найнижчі відсотки (45,76\%), тому їм властива схильність приховувати свої недоліки, стримувати бажання і контролювати почуття.

Аналізуючи шкали Самоповага» та «Самоприйняття», бачимо, що за першим параметром середні показники всіх опитаних $€$ 
вищими ніж за другим (першокурсники 51,43\% і 45,22\% відповідно, другокурсники $54,54 \%$ і 46,33\%, третьокурсники - 51,81\% і $44,90 \%$, випускники - 52,19\% і 48,72\%). Це дає підстави стверджувати про переважаючу здатність у випробуваних цінувати та поважати свої переваги, позитивні якості характеру, а ніж приймати себе таким, яким є, незалежно від оцінки своїх достоїнств і недоліків.

Найвищий середній показник для досліджуваної вибірки серед усіх шкал виявлений за параметром «Уявлення про природу людини» (52,95\%). Так, згідно отриманих значень п’ятикурсникам $(55,16 \%)$ та першокурсникам (54,82\%) властива схильність позитивно сприймати оточуюче середовище, щирість та гармонійність в міжособистісних взаєминах. Найнижчий показник у студентів другого курсу $(48,47 \%)$, це можна інтерпретувати як деяку недовіру до людей.

За допомогою шкали «Синергія» ми дослідили на скільки майбутні фахівці здаті до цілісного сприйняття оточуючого середовища. Згідно таблиці 1 високо розвинена ця здатність у п'ятикурсників (56,75\%). Результати другокурсників (49,37\%) та третьокурсників (49,48\%) знаходяться нижче показника студентів першого курсу (50,66\%), який недосягає навіть оптимального значення (55-56\%), а це свідчить про невміння цілісно відображати світ та людей, появу недовіри.

За параметром «Прийняття агресії», виявили у всіх досліджуваних недостатній розвиток здатності приймати власну роздратованість, гнів та агресивність як природні людські прояви. Про що свідчать отримані показники, у першокурсників - це 48,27\%, у студентів другого курсу - 47,66\%, у третьокурсників $-48,88 \%$ і у випускників - 49,32\%.

3 таблиці 1 бачимо, що до третього курсу поступово знижуються показники за шкалами «Контактність» та «Пізнавальні потреби», це вказує на недостатнє вміння швидко встановлювати глибокі та міцні емоційно насичені контакти 3 іншими людьми та відсутність прагнень до набуття нових знань. Однак, на випускному курсі фіксуємо зростання названих показників.

За шкалою «Креативність» діагностували у студентів розвиток прагнення до творчості. Так, найбільш творчо ставляться до життя, хочуть досягнути внутрішньої гармонії другокурсники (49,31\%). Студенти третього курсу $(45,81 \%)$ навпаки найменше проявляють схильність до креативності, вважаючи, що в ній неможливо знайти смисл життя.

Отже, підсумовуючи проведене дослідження, діагностували низький рівень тенденції до самоактуалізації у всіх студентів, що проявляється у недостатньому прагненні до самопізнання, саморозвитку, самовдосконаленні, самозміни та самоздійснення. Студенти не бажають досягати поставленої мети, отримувати певні результати, максимально виявляти кращі якості своєї особистості, не прагнуть долати несприятливий досвід, бути відкрити- 
ми у внутрішніх та зовнішніх переживанях. Наявні цілі, погляди, цінності та мотиви не спонукають випробуваних до досягнення у професії свого максимуму. Проте досліджувані вміють цінувати та поважати свої переваги, позитивні якості характеру та вцілому позитивно сприймати оточуюче середовище, проявляти щирість та гармонійність в міжособистісних взаєминах.

Висновки 3 даного дослідження і перспективи подальших розвідок у даному напрямку. Таким чином, самоактуалізація це безперевний рух у напрямку особистісного та професійного зростання. Прагнення до самоактуалізації $\epsilon$ провідним і найвищим мотивом у діяльності і поведінці людини, природнім, закономірним і необхідним процесом життя. Тенденція до повної реалізації себе та власних потенціальних ресурсів $є$ інтегративним показником розвитку суб'єктної позиції особистості, яка виражає систему особистісно -значущих, ціннісно-смислових ставлень до себе, своєї діяльності та оточуючих. Експериментальне дослідження студентів-майбутніх фахівців різних спеціальностей показало низьку тенденцію до самоктуалізації. На нашу думку, однією із причин такого стану є недостатнє сприяння розгортанню суб'єктності, актуалізації суб'єктного потенціалу в умовах освітнього середовища вищої школи. Виступаючи пасивними об'єктами освітніх впливів, студенти не мають достатніх можливостей реалізації прагнення до самоактуалізації. Відтак, у майбутніх дослідженнях ставимо собі за мету вивчення та обгрунтування чинників та умов які б сприяли розвитку суб'єктної позиції сучасного студента-майбутнього фахівця.

\section{Перелік використаних джерел:}

1. Адлер А. Индивидуальная психология // Теории личности в западноевропейской и американской психологии / Под ред. Райгородского Д. Я. - Самара: Изд. дом «Бахрах», 1996. - С.154-180.

2. Блинова Ю. Л. Субъектная позиция педагога: теория и психолого-акмеологическое сопровождение. - Казань: ТГГПУ, 2010. - 202c.

3. Загальна психологія. / За загальною редакцією академіка Максименка С.Д. Підручник. - 2-е вид., переробл. і доп. - Вінниця: Нова Книга, 2004. - 704c.

4. Копеиь Л. В. Психологія особистості: Навч. посіб. для студ. вищ. навч. закл. - К.: Вид. дім «КиєвоМогилянська академія», 2007. - 470 с.

5. Роджерс K. Клиент-центрированная терапия. - Киев, 1997. - 320c.

6. Радчук Г. К. Аксіопсихологія вищої школи: Моногр. / Галина Кіндратівна Радчук - Тернопіль: ТНПУ ім. В. Гнатюка, 2014 - 380c.

7. Шmеnа О. С. Пропріум зрілої особистості // Практична психологія та соціальна робота. - 2004.-№2. - С.2632.

\section{References (Transliteration):}

1. Adler A. Individualnaya psihologiya // Teorii lichnosti $\mathrm{v}$ zapadnoevropeyskoy i amerikanskoy psihologii / Pod red. Raygorodskogo D. Ya. - Samara: Izd. dom «Bahrah», 1996. - S.154-180.

2. Blinova Yu. L. Subektnaya poziciya pedagoga: teoriya $\mathrm{i}$ psixologo-akmeologicheskoe soprovozhdenie. - Kazan': TGGPU, 2010. - 202s.

3. Zagalna psychologiya. / $\mathrm{Za}$ zagalnoyu redakciyeyu 
akademika Maksymenka S.D. Pidruchnyk. - 2-e vyd., pererobl. i dop. - Vinnycya: Nova Knyga, 2004. - 704s.

4. Kopecz L. V. Psyxologiya osobystosti: Navch. posib. dlya stud. vyshh. navch. zakl. - K.: Vyd. dim «KyyevoMogylyanska akademiya», 2007. - $470 \mathrm{~s}$.

5. Rodzhers K. Klient-tsentrirovannaya terapiya. - Kiev, 1997. - 320s.

6. Radchuk G. K. Aksiopsychologiya vyshhoyi shkoly : Monogr. / Galyna Kindrativna Radchuk - Ternopil:TNPU im. V. Gnatyuka, $2014-380$ s.

7. Shtepa O. S. Proprium zriloyi osobystosti // Praktychna psychologiya ta socialna robota. - 2004. \#2. - S.26-32.

\section{Vovk Valentina}

PhD student at Department of pedagogical and age psychology Precarpathian National University of Vasyl Stefanyk, Ternopol (Ukraine)

\section{THE DESIRE FOR SELF-ACTUALIZATION AS AN INTEGRATED INDICATOR OF THE MODERN STUDENT'S SUBJECTIVE POSITION}

\section{ABSTRACT}

The problem of the formation of the individual's subjective position during professional education and professional activities is widely presented in the psychologists's and educators's researchs (G. Aksonova, Yu. Blinova, E. Zalevskaya, E. Dvoryankina, Yu. Kuznetsova, A. Lebedev, T. Olkhova and G. Radchuk, etc.). The researchers are paying attention on the development of the students's subjective position in the educational, professional and creative activity, they are learning the process of its formation at the stage of self-actualization and during advanced training.
In our opinion, the subjective position of a future specialist it is a system of meaningful, valuable and semantic attitudes to the learning, to the chosen profession, to himself as a specialist and to the own future professional way that are aimed at self-development and self-actualization. Agreeing with N. Boritko, F.I Bliyeva, G. Radchuk we think that the desire for selfactualization is an integrated indicator of the subjective position of a future specialist. The desire for self-actualization is a leading motive that prompts for maximum achievements in the future profession.

The analysis of psychological and pedagogical literature makes it possible to determine the self-actualization of the personality in educational and professional activity as the process of the most complete embodiment of the student's own intellectual, spiritual, moral, creative, communicative, energetic and other potentialities of the person in educational and professional activity, in communication and in the work.

When we did a research we found that all students have a low level of self-actualization. It is manifested in the lack of desire for selfknowledge, self-development, self-improvement, self-transformation. The students do not want to achieve the own goal, do not want to get some results, do not want to show the best qualities of they personality, as much as possible. They do not strive in overcome unfavorable experience and do not strive to be open in internal and external experiences. They goals, views, values and 
motives doesn't encourage to achieve their maximum in the profession. However, the researchers can appreciate and respect their advantages and positive qualities and positively perceive the environment, show sincerity and harmony in interpersonal relationships.

In our opinion one of the reasons for such a state is the inadequate promotion of the development of subjectivity, actualization of the subject potential in the conditions of the educational environment of higher education. Being passive objects of educational influences, students do not have sufficient opportunities to realize the desire for self-actualization. Therefore, all of the above issues actualizes the problem of creation the favorable conditions for the development of a subjective position and the formation of the integrity of the personality of a modern student-future specialist.

Key words: the position, the subject position of the future specialist, the self-actualization, the sensitivity, the autonomy, the selfunderstanding, the self-esteem, the synergy.

\section{Вовк Валентина Олегівна}

Аспирантка кафедры педагогической и возрастной психологии ГВУЗ «Прикарпатский национальный университет имени Василия Стефаника», г. Тернополь (Украина)

\section{СТРЕМЛЕНИЕ К} САМОАКТУАЛИЗАЦИИ КАК ИНТЕГРАТИВНЫЙ ПОКАЗАТЕЛЬ РАЗВИТИЯ СУБЪЕКТНОЙ ПОЗИЦИИ СОВРЕМЕННОГО СТУДЕНТА
Проблема становления субъектной позиции личности в процессе профессионального образования и профессиональной деятельности представлена достаточно широко в работах психологов и педагогов (Г. И. Аксенова, Ю. Л. Блинова, Е. Н. Залевский, Е. К. Дворянкина, Ю. Л. Кузнецова, А. С. Лебедев, Т. А. Ольховая и Г. К. Радчук и др.). Исследователи акцентируют внимание на развитие субъектной позиции студентов в учебно-профессиональной и творческой деятельности, изучается процесс ее формирования на этапе самоактуалиации и в процессе повышения квалификации и др.

По нашему мнению, субъектная позиция будущего специалиста - это система личностно-значимых, ценностно-смысловых отношений к процессу обучения, к избранной профессии, к себе как к специалисту и своему будущему профессиональному пути, направленных на саморазвитие и самоактуализацию. Соглашаясь с Н. М. Боритко, Ф. И. Блиевой, О. А. Мацкайловою, Г. К. Радчук, считаем, что интегративным показателем субъектной позиции студента является стремление к самоактуализации, которая является ведущим мотивом, побуждающим к максимальным достижениям в будущей профессии.

Анализ психолого-педагогической литературы позволяет определить самоактуализацию личности в учебно-профессиональной деятельности как процесс наиболее полного воплощения студентом собственного интел- 
лектуального, духовного, нравственного, творческого, коммуникативного, энергетического и других потенциалов личности в учебно-профессиональной деятельности, общении, труде и досуге.

По результатам проведенного исследования особенностей и уровня проявления самоактуализации современных студентов в процессе профессиональной подготовки в вузе, обнаружили низкий уровень тенденции к самоактуализации у всех студентов, что проявляется в недостаточном стремлении к самопознанию, саморазвитии, самосовершенствовании, самоизменении.

Студенты не хотят достигать поставленной цели, получать определенные результаты, максимально проявлять лучшие качества своей личности, не хотят преодолевать неблагоприятный опыт, быть открытыми во внутренних и внешних переживаний.

Имеющиеся цели, взгляды, ценности и мотивы не побуждают испытуемых до достижения в профессии своего максимума. Однако исследуемые умеют ценить и уважать свои преимущества, достоинства характера и в целом положительно воспринимают окружающую среду, проявляют искренность и гармоничность в межличностных отношениях.

По нашему мнению, одной из причин такого положения является недостаточное содействие развертыванию субъектности, актуализации субъектного потенциала в условиях образовательной среды высшей школы.
Выступая пассивными объектами образовательных воздействий, студенты не имеют достаточных возможностей реализации стремления к самоактуализации. Следовательно, все вышесказанное актуализирует проблему создания благоприятных условий для развития субъектной позиции и становления целостности личности современного студентабудущего специалиста.

Ключевые слова: позиция, субъектная позиция будущего специалиста, самоактуализация, сенситивнисть, автономность, самопонимания, самоуважение, синергия.
Дата отримання статті: 02.07.2017

Дата рекомендації до друку: 03.07.2017 